\title{
Exploratory Analysis of Sparkling Wines Based in the Combined Data of Stable Isotope Analysis with Physicochemical Variables and Volatile Profile
}

\author{
Victor H. J. M. dos Santos, ${ }^{a}$ Paulo G. Celso, ${ }^{b}$ Artur L. G. Rocha, ${ }^{b}$ Samuel Giovanaz, ${ }^{b}$ \\ Carolina Z. Guerra, ${ }^{b}$ Jessica P. Pires, ${ }^{a}$ Pâmela M. Engelmann ${ }^{a}$ and \\ Luiz F. Rodrigues*,a
}

\begin{abstract}
anstituto do Petróleo e dos Recursos Naturais, Pontifícia Universidade Católica do Rio Grande do Sul, Av. Ipiranga, 6681, 90619-900 Porto Alegre-RS, Brazil

${ }^{b}$ Laboratório Nacional Agropecuário (Lanagro-RS), Ministério da Agricultura, Pecuária e Abastecimento, Estrada da Ponta Grossa, 3036, 91780-580 Porto Alegre-RS, Brazil
\end{abstract}

\begin{abstract}
This work performs an exploratory analysis of the sparkling wines from the state of Rio Grande do Sul, Brazil. Samples of traditional sparkling wine and Moscatel sparkling wine were analyzed and chemometrics tools were applied to physicochemical, gas chromatography and stable carbon isotope analysis. The carbon isotope ratio $\left(\delta^{13} \mathrm{C}^{-\mathrm{CO}_{2}}\right)$ of the samples presents great heterogeneity and confirm that the isotopic signature of the $\mathrm{CO}_{2}$ could be derived from the fermentation of $\mathrm{C} 4$ sugar. The principal component analysis (PCA) was capable to discriminate and classify the samples in their respective groups and combined data approach was especially important to identify the correlation between the studied variables. With the increasing production of sparkling wines in Brazil, this work helps to evaluate the standards of the local sparkling wines.
\end{abstract}

Keywords: sparkling wine, chemometrics, IRMS, stable isotope, food chemistry

\section{Introduction}

Sparkling wine, from a chemical point of view, is a hydro-alcoholic solution supersaturated with $\mathrm{CO}_{2}$, which is in equilibrium between the liquid and gas phases. ${ }^{1}$ According to the International Organization of Vine and Wine (OIV), ${ }^{2}$ an intergovernmental organization and scientific and technical reference in Oenology, the term sparkling wine is applied to the product derived from grapes, must and wine, where the $\mathrm{CO}_{2}$ is derived from natural fermentation and the must has been treated, as per the recommendation of OIV.

Sparkling wines are normally derived from two fermentations steps. The first step turns the must in order to obtain the base wine, while the second step is conducted through the Champenoise or Charmat methods to produce the $\mathrm{CO}_{2}$. These two methods differ in the yeast conversion of glucose to ethanol, the ageing time and ageing container (bottle or isobaric tanks). ${ }^{3}$

The European Union countries are the largest wine producers, led by France and followed by Italy and Spain. ${ }^{4}$

*e-mail: frederico.rodrigues@ pucrs.br
Five EU countries (France, Germany, Spain, Italy and Russia) are responsible for $74 \%$ of the world production of sparkling wine and between the years of 2003 and 2013, these production increased by $40 \%$, reaching 17.3 million hectoliters per year. ${ }^{2}$ This increase is generally attributed to a change in the way the product is consumed, which has slowly changed from festive to more regular consumption. ${ }^{2}$

Brazil is part of a new group of winegrowing countries and has slowly increased their importance in the international wine market. Between 2003 and 2013, the production of sparkling wine recorded an increase of $248 \%$, and today Brazil is the sixteenth largest producer, producing 2.7 million hectoliters of wine per year. ${ }^{2,4}$ The most southern state of Brazil, the Rio Grande do Sul (RS), is the principal area of grape cultivation, being responsible for more than $90 \%$ of Brazilian wine production. The sparkling wine industry has an economic and social importance for RS and the principal producing regions are: Serra Gaúcha, Serra do Sudeste, Campos de Cima da Serra and Campanha Gaúcha. ${ }^{5-8}$

Even with local products obtaining international acceptance, the burst in the production of sparkling wine in the last fifteen years and the small amount of research 
reveals the necessity of further studies in order to establish standards and typicity of the local production. Toward this end, chromatographic, spectroscopic and spectrometric methods are some of the most established analytical methods for assessment of the content of trace elements, phenolic compounds, volatile profile and stable isotope ratios.

For stable isotopic analysis, there are two main ways to conduct analysis: nuclear magnetic resonance (NMR) and isotope ratio mass spectrometry (IRMS). ${ }^{9}$ These isotopic ratio techniques have been widely applied to identification of geographical origin as well as to authentication/ traceability of sparkling and non-sparkling beverages such as ciders, ${ }^{10-12}$ beer, ${ }^{13}$ juice ${ }^{14}$ and wine. ${ }^{15,16}$

According to the Brazilian legislation ${ }^{17}$ (decree No. 8,198/2014) the addition of saccharose to the Vitis vinifera musts is allowed in the first fermentation in order to increase the ethanol content of up to $2 \% \mathrm{v} / \mathrm{v}$, as well to the second fermentation of sparkling wines until $1.5 \% \mathrm{v} / \mathrm{v}$. From this, the isotopic analysis is an important tool for the quality control of the sparkling wine produced in Brazil, since the sugar could be added in several production steps and there is an isotopic distinction between grape sugar and others carbohydrate feedstock as sugar cane. ${ }^{18}$

Previous research ${ }^{19}$ has shown the efficacy of using stable carbon isotopes to assess sparkling wine composition and for quality control. Dunbar ${ }^{19}$ has studied the possible origins of the $\mathrm{CO}_{2}$ in order to take more information about the methods applied for production of the sparkling wine. $\mathrm{He}$ has found that, by analyzing the carbon isotope ratio of the $\mathrm{CO}_{2}$ and ethanol, it is possible to get insight about the production method and the possible origins of the $\mathrm{CO}_{2}$ inside the bottle; amongst the 10 commercial samples, all the possibilities of $\mathrm{CO}_{2}$ sources $(\mathrm{C} 3$ sugar, $\mathrm{C} 4$ sugar, mixture of $\mathrm{C} 3 / \mathrm{C} 4$ and food grade $\mathrm{CO}_{2}$ ) were detected.

Similarly, Martinelli et al. ${ }^{18}$ have investigated the stable carbon isotopic composition of the wine and of the $\mathrm{CO}_{2}$ bubbles produced during the second fermentation of many sparkling wines from different countries around the world. They have concluded that the measurement of $\delta^{13} \mathrm{C}$ values could be used to differentiate the content of grape or $\mathrm{C} 4$ sugar added to the product and that the carbon isotope ratios of European and South American sparkling wines were significantly more depleted of ${ }^{13} \mathrm{C}$ than Brazilian wines.

In an innovative approach, Calderone et al.$^{20}$ present an advantageous method for analyses the $\delta^{13} \mathrm{C}$ values of $\mathrm{CO}_{2}$ from the headspace of sparkling drinks wherein headspace sampling is followed by direct injection of the sample into a gas chromatograph with an isotope ratio mass spectrometer, through a combustion interface (GC-C-IRMS); this configuration requires no purification and presents good reproducibility. Already Adami et al. ${ }^{16}$ present a method which, from the isotopic ratios of $\delta^{13} \mathrm{C}$ of the ethanol and $\delta^{18} \mathrm{O}$ of the water content of wine, was capable to find the relationship between the grape variety, the wine type and the geographic location.

In many cases, it is necessary to perform several tests to reach the expected results and a multivariate approach is one of the best ways to perform high throughput data analysis. Several works have been published with the aim of establishing patterns in food chemistry characterization and adulteration control and the multivariate approach has been applied to sparkling wine analysis.

Jos et $a l .{ }^{21}$ have studied the possibility of using the mineral content of cava and champagne sparkling wines differentiated between them through chemometrics tools, linear discriminant analysis (LDA) and soft independent modeling of class analogy (SIMCA). The main descriptors found were $\mathrm{Zn}, \mathrm{Sr}, \mathrm{Pb}, \mathrm{Na}, \mathrm{Cu}, \mathrm{Ni}, \mathrm{As}, \mathrm{P}$ and $\mathrm{Cd}$ contents and both models presented excellent classification capability, with $100 \%$ of samples correctly classified.

A combined data approach was proposed by Pérez-Magariño et al. ${ }^{22}$ which have performed the discriminant analysis of sparkling wines from Spanish grape varieties through data profiles of volatile compounds, amino acids and biogenic amines. They found that is possible to differentiate the sparkling wines by grape variety and by ageing time, and to enhance this result, they selected the variables that presented the higher discriminating capability.

The isotope data was proved to be useful to perform discriminant analysis. Scampicchio et al..$^{23}$ use several combinations of techniques to trace the geographical origin of alpine milk. They apply different combinations of data from gas chromatography with flame ionization detector (GC-FID), mid-infrared spectroscopy (MIR), near-infrared spectroscopy (NIRS) and IRMS through partial least squares discriminant analysis (PLS-DA) and the best results were obtained through the combination of GC-FID and IRMS data.

In a similar approach, Hohmann et al. ${ }^{24}$ studied the combination of MIR, ${ }^{1} \mathrm{H}$ NMR and IRMS data to distinguish between organic and conventional tomatoes and obtained the best results for the combined data from ${ }^{1} \mathrm{H}$ NMR + MIR + IRMS with $95-100 \%$ of samples correctly classified.

There is an improvement in people's living standards and consumers are becoming increasingly demanding about the authenticity of food. ${ }^{25,26}$ With the increase of production of sparkling wines in Brazil, and the small amount of research dedicated to controlling the quality of these products, the aim of this work was to perform exploratory analysis of the sparkling wines from the state 
of Rio Grande do Sul. To our knowledge, this work was the first developed by applying chemometrics tools in a combined data approach for chemical characterization through the combination of $\delta^{13} \mathrm{C}$ of $\mathrm{CO}_{2}$ from the headspace of bottle with physicochemical parameters, and gas chromatography analysis.

\section{Experimental}

This study covers only the quality control parameters that are defined by the current Brazilian regulations and follow the classification criteria established by the Ministry of Agriculture, Livestock and Supply (MAPA). All the samples analyzed in this work were produced in wineries from the cities Bento Gonçalves, Caxias do Sul, Farroupilha, Flores da Cunha and Garibaldi localized in Serra Gaúcha, a region of Rio Grande do Sul State, in a total of thirty-six samples. The geographical locations of Rio Grande do Sul and the cities from where the samples were originated could be found represented in the Supplementary Information section (Figure S1) while the limits for the controlled parameters are presented in Table S1.

\section{Materials}

The reagents used in this work without prior treatments were: iodine (Panreac, $99.8 \%$ ), potassium iodide (Dinâmica, $\geq 99 \%$ ), soluble starch (Merck), sodium hydroxide (CRQ, 99\%), copper(II) sulfate pentahydrate (Sigma-Aldrich, $\geq 98 \%$ ), sulfuric acid (Panreac, 96\%), sodium potassium tartrate tetrahydrate (Vetec, $\geq 99 \%$ ), $D$-glucose (CRQ, 99\%), absolute ethyl alcohol (Êxodo Científica, $\geq 99.8 \%$ ), acetaldehyde (Fluka, $\geq 99 \%$ ), ethyl ethanoate (Fluka, $\geq 99.9 \%$ ), 1-propanol (Fluka, $\geq 99.9 \%$ ), 2-methyl1-propanol (Fluka, 99.5\%), 1-butanol (Fluka, $\geq 99.9 \%$ ), Methanol (Sigma-Aldrich, 99.8\%), 2-butanol (SigmaAldrich, 99\%), 2-methyl-1-butanol (Sigma-Aldrich, 99\%) and 3-methyl-1-butanol (Sigma-Aldrich, 99\%).

\section{Sample classification of Brazilian sparkling wines}

In this section, the specifications of the samples studied in this work according to Brazilian regulation are presented. The samples are classified according to three parameters: class, color and residual sugar content, following the recommendations of the Brazilian law No. 10,970/2004. ${ }^{27}$

\section{Classification parameter (class)}

The product categories analyzed in this work are briefly described, which include: traditional sparkling wine and Moscatel sparkling wine.
Traditional sparkling wine is the wine produced from fermentation of grape must, with alcoholic grade ranging from 10 to $13 \%$, minimum pressure of $4 \mathrm{~atm}$ and $\mathrm{CO}_{2}$ obtained solely from the fermentation of natural carbohydrate..$^{28}$

Moscatel sparkling wine is an "Asti" made wine produced from the must of grapes of Moscatel variety and was produced by a single fermentation that takes place until the ethanol content reaches close to $10 \%(\mathrm{v} / \mathrm{v})$ and leaves a considerable amount of residual sugar. ${ }^{6}$ The fermentation step are stopped using a combination of physical (cooling and filtration) and chemical agents (sulfur dioxide). ${ }^{29}$ This sparkling wine also could be found by their synonyms: Moscato, Muscatel and Muscat. It contains an alcoholic grade ranging from 7 to $10 \%$, minimum pressure of $4 \mathrm{~atm}$, at least 20 grams of residual sugar and $\mathrm{CO}_{2}$ obtained solely from fermentation of natural carbohydrate. ${ }^{28}$

\section{Classification parameter (color)}

According to color, wines can be classified in white wine, red wine and rosé wine.

\section{Classification parameter (residual sugar content)}

Each class of wine has a different classification according to its residual sugar content. In this work, two classes for residual sugar content were found for the traditional sparkling wine, which were: brut, with a residual sugar content from 8 to 15 grams per liter, and demi-sec, with a residual sugar content from 20 to 60 grams per liter. All Moscatel sparkling wine samples presented residual sugar content close to or above 60 grams per liter. The analyzed samples and their respective classifications are presented in Table 1.

\section{Physicochemical analysis}

The physicochemical analysis was carried by the MAPA of the state of Rio Grande do Sul following the standard methods established by the institution. ${ }^{30,31}$ The parameters analyzed were: pressure, density, total dry extract, alcoholic grade, reduced dry extract, total sugar content, $\mathrm{pH}$, total acidity and sulfur dioxide $\left(\mathrm{SO}_{2}\right)$. Table 2 summarizes the methods for each physicochemical analysis.

\section{Gas chromatography analysis}

The gas chromatography (GC) analysis was carried out by MAPA, following the standard methods established by the institution. The compounds quantified were: acetaldehyde, ethyl ethanoate, 1-propanol, 2-methyl- 
Table 1. Identification of sparkling wine samples

\begin{tabular}{|c|c|c|c|c|c|c|c|}
\hline \multirow{2}{*}{$\begin{array}{l}\text { Sample } \\
\text { (ID) }\end{array}$} & \multicolumn{3}{|c|}{ Sparkling wine identification } & \multirow{2}{*}{$\begin{array}{l}\text { Sample } \\
\text { (ID) }\end{array}$} & \multicolumn{3}{|c|}{ Sparkling wine identification } \\
\hline & Class & Color & Sugar content & & Class & Color & Sugar content \\
\hline 1 & Moscatel sparkling wine & $\mathrm{C}$ & $\mathrm{C}$ & 19 & Moscatel sparkling wine & $\mathrm{C}$ & $\mathrm{C}$ \\
\hline 2 & Moscatel sparkling wine & $\mathrm{C}$ & $\mathrm{C}$ & 20 & Moscatel sparkling wine & rosé & $\mathrm{C}$ \\
\hline 3 & Moscatel sparkling wine & $\mathrm{C}$ & $\mathrm{C}$ & 21 & sparkling wine & white & brut \\
\hline 4 & Moscatel sparkling wine & $\mathrm{C}$ & $\mathrm{C}$ & 22 & sparkling wine & white & demi-sec \\
\hline 5 & Moscatel sparkling wine & $\mathrm{C}$ & $\mathrm{C}$ & 23 & sparkling wine & white & brut \\
\hline 6 & Moscatel sparkling wine & $\mathrm{C}$ & $\mathrm{C}$ & 24 & sparkling wine & white & demi-sec \\
\hline 7 & Moscatel sparkling wine & $\mathrm{C}$ & $\mathrm{C}$ & 25 & sparkling wine & white & brut \\
\hline 8 & Moscatel sparkling wine & $\mathrm{C}$ & $\mathrm{C}$ & 26 & sparkling wine & white & brut \\
\hline 9 & Moscatel sparkling wine & $\mathrm{C}$ & $\mathrm{C}$ & 27 & sparkling wine & white & brut \\
\hline 10 & Moscatel sparkling wine & $\mathrm{C}$ & $\mathrm{C}$ & 28 & sparkling wine & rosé & brut \\
\hline 11 & Moscatel sparkling wine & $\mathrm{C}$ & $\mathrm{C}$ & 29 & sparkling wine & white & demi-sec \\
\hline 12 & Moscatel sparkling wine & $\mathrm{C}$ & $\mathrm{C}$ & 30 & sparkling wine & rosé & demi-sec \\
\hline 13 & Moscatel sparkling wine & $\mathrm{C}$ & $\mathrm{C}$ & 31 & sparkling wine & white & demi-sec \\
\hline 14 & Moscatel sparkling wine & $\mathrm{C}$ & $\mathrm{C}$ & 32 & sparkling wine & rosé & brut \\
\hline 15 & Moscatel sparkling wine & $\mathrm{C}$ & $\mathrm{C}$ & 33 & sparkling wine & white & brut \\
\hline 16 & Moscatel sparkling wine & rosé & $\mathrm{C}$ & 34 & sparkling wine & white & brut \\
\hline 17 & Moscatel sparkling wine & $\mathrm{C}$ & $\mathrm{C}$ & 35 & sparkling wine & white & brut \\
\hline 18 & Moscatel sparkling wine & rosé & $\mathrm{C}$ & 36 & sparkling wine & white & demi-sec \\
\hline
\end{tabular}

C: characteristic.

Table 2. Physicochemical analysis of sparkling wine

\begin{tabular}{|c|c|}
\hline Parameter & Reference \\
\hline Pressure & OIV-MA-AS314- $02^{30}$ \\
\hline Density & OIV-MA-AS2-01A ${ }^{30}$ \\
\hline Alcoholic grade & OIV-MA-AS312-01A ${ }^{30}$ \\
\hline Total dry extract & OIV-MA-AS20-3B ${ }^{30}$ \\
\hline Reduced dry extract & OIV-MA-AS20-3B ${ }^{30}$ \\
\hline Total sugar content & OIV-MA-AS311-01A \\
\hline $\mathrm{pH}$ & OIV-MA-AS313-15 $5^{30}$ \\
\hline Total acidity & Method 05-MAPA Standard ${ }^{31}$ \\
\hline Sulfur dioxide & Method 16-MAPA Standard ${ }^{31}$ \\
\hline
\end{tabular}

1-propanol, 1-butanol, methanol, 2-butanol, 2-methyl1-butanol and 3-methyl-1-butanol, all data were express in $\mathrm{mg} \mathrm{L}^{-1}$.

The gas chromatography (GC) analyses were performed in an MDGC-MS Shimadzu (GC2010Plus/FID coupled to a GC2010Plus/MS QP2010 Ultra) equipped with an Auto Injector AOC500. The capillary column used in the first GC was a fused silica polar column with polyethylene glycol cover (Agilent J\&W CP-Wax $57 \mathrm{CB}-50 \mathrm{~m} \times 0.25 \mathrm{~mm}$ internal diametrer $\times 0.2 \mu \mathrm{m}$ ). A fused silica low-polarity column with diphenyl dimethyl polysiloxane phase $\left(\mathrm{Rtx}^{\circledR}\right.$-5MS-30 $\mathrm{m} \times 0.25 \mathrm{~mm}$ ID $\left.\times 0.25 \mu \mathrm{m}\right)$ was used in the second GC.

The injector $\left(230^{\circ} \mathrm{C}\right)$ applied a split ratio of 1:20 with helium as the carrier gas (column flow of $1.8 \mathrm{~mL} \mathrm{~min}{ }^{-1}$ ) and the FID set at $250^{\circ} \mathrm{C}$. The general operating procedure starts with the $1^{\text {st }} \mathrm{GC}$ started at $50^{\circ} \mathrm{C}$ (hold 4 min) increased at a heating rate of $5{ }^{\circ} \mathrm{C} \mathrm{min}^{-1}$ up to $110^{\circ} \mathrm{C}$, followed by an increase in the heating rate at $15{ }^{\circ} \mathrm{C} \mathrm{min}^{-1}$ to $180{ }^{\circ} \mathrm{C}$ (hold $8 \mathrm{~min}$ ). For the $2^{\text {nd }} \mathrm{GC}$, the initial temperature started at $70{ }^{\circ} \mathrm{C}$ (hold $10 \mathrm{~min}$ ) increased at a heating rate of $10{ }^{\circ} \mathrm{C} \mathrm{min}-1$ to $170{ }^{\circ} \mathrm{C}$ (hold $3 \mathrm{~min}$ ). The programmed temperature in $2^{\text {nd }} \mathrm{GC}$ was adjusted for each analyte to be isolated by the heartcut (GC/GC interface).

Isotopic analysis of $\delta^{13} \mathrm{C}$ of $\mathrm{CO}_{2}$

The isotope ratio mass spectrometer (IRMS) is an instrument used to analyze the ratio of stable isotopes of carbon $\left({ }^{13} \mathrm{C} /{ }^{12} \mathrm{C}\right){ }^{32,33}$ The method of analysis of the $\delta^{13} \mathrm{C}$ from the $\mathrm{CO}_{2}$ taken from the sample headspace involves plugging a modified sampler through the cork of the bottle at room temperature. ${ }^{30}$ The device comprises a stainless steel needle for puncturing the cork, a needle valve for flow 
control and a rubber septum for coupling the GC inlet. A diagram of the device is shown in Figure 1.

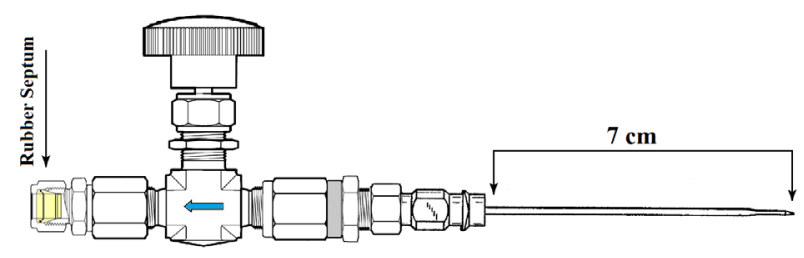

Figure 1. $\mathrm{CO}_{2}$ sampling device from bottle headspace.

Before performing the analysis, the sampler is first purged with helium and the first $50 \mathrm{~mL}$ of gas are disposed. Then the samples proceed to analysis by GC-IRMS. The isotope ratio measurements were performed and referenced to an international standard Vienna Pee Dee Belemnite (VPDB) in per mille unit (\%o). The isotope ratio calculation is shown in equation 1 .

$\delta^{13}$ sample $=\frac{\left({ }^{13} \mathrm{C} /{ }^{12} \mathrm{C}\right)_{\text {sample }}-\left({ }^{13} \mathrm{C} /{ }^{12} \mathrm{C}\right)_{\mathrm{VPDB}}}{\left({ }^{13} \mathrm{C} /{ }^{12} \mathrm{C}\right)_{\mathrm{VPDB}}} \times 1000$

The equipment used for the analysis was a Trace GC gas chromatograph, with a GC IsoLink module, coupled to the IRMS Delta V Plus (Thermo Fisher Scientific Company). The combustion reactor temperature was $1000{ }^{\circ} \mathrm{C}$. A fused silica column of Supelco-Carboxen Plot 1006, $32 \mathrm{~m} \times 0.32 \mathrm{~mm}$, was used and operated under a heating ramp from 70 to $150{ }^{\circ} \mathrm{C}$ over the 10 minutes of analysis time. Before each chromatographic run, three pulses of standardized $\mathrm{CO}_{2}\left(\delta^{13} \mathrm{C}=-32.848 ; \delta^{18} \mathrm{O}=-23.164\right)$ were injected into the system to perform the isotopic ratio calculation.

\section{Multivariate data analysis}

In this work, the chemometrics tool principal component analysis (PCA) was used for exploratory analysis of the samples and to fill the missing data, by performing a reconstruction of the values based on PCA model of the data. ${ }^{34-36}$ All data were analyzed using the software The Unscrambler X $10.4^{\circledast}$ (CAMO Software Company), using the default settings of the software and the algorithms without prior modification.

\section{Results and Discussion}

\section{Physicochemical analysis}

Physicochemical analysis was carried out in order to evaluate the characteristics of each product and verify if the values obtained correlate to the identity and quality standards set by the Ministry of Agriculture, Livestock and Supply and to determine if they are likely for commercialization in the Brazilian market. All the sparkling wines evaluated were within a normal range of expected characteristics according to the quality standards for each product class. The evaluated parameters are presented in Table 3 for each of the wine samples studies herein.

The pressures in the bottles were in accordance with the respective classes of sparkling wine, which was higher than 4 atm for traditional sparkling wine and Moscatel sparkling wine and at least $3 \mathrm{~atm}$ for sparkling sweet wine.

The density could be used as a control parameter for monitoring the progress and regularity of the fermentation process and are a parameter poorly explored in the discussion of the analysis of wines. The densities of the samples measured herein were $0.993-1.004 \mathrm{~g} \mathrm{~cm}^{-3}$ for traditional sparkling wine, which are in accordance with the typical range of densities for traditional sparkling wine (0.9990-0.996 $\left.\mathrm{g} \mathrm{cm}^{-3}\right),{ }^{37}$ and $1.020-1.029 \mathrm{~g} \mathrm{~cm}^{-3}$ for the Moscatel sparkling wines. This difference is expected due the higher amount of residual sugar and lower alcohol content of the Moscatel sparkling wine.

Although ethanol is the main constituent of the alcoholic fraction of sparkling wine, other secondary metabolites such as glycerol, secondary alcohols and methanol could be present and are mainly produced in the fermentation step. ${ }^{37}$ The alcoholic ranges measured for the samples herein were 7.0-9.0\% (v/v) for Moscatel sparkling wine and $10.6-12.3 \%(\mathrm{v} / \mathrm{v})$ for traditional sparkling wine.

The dry extract has an important role in the sense of texture afforded by wine and comprises the fixed fraction of the wine as mineral content, organic acid, phenolic compounds, and residual sugar, among others. The total dry extract is closely linked to the density but not necessarily linked to the alcohol levels. ${ }^{38,39}$ The following quantities were obtained for the Moscatel sparkling wine: total dry extract, 81-107.1 $\mathrm{g} \mathrm{L}^{-1}$; reduced dry extract, 19.18-36.56 $\mathrm{g} \mathrm{L}^{-1}$; and total sugar content $59.86-74.75 \mathrm{~g} \mathrm{~L}^{-1}$. The high values of these three parameters are characteristics of the winemaking style similar to "Asti Spumante," where the fermentation is stopped in order to reach a medium alcoholic strength and leave a considerable amount of residual sugar. ${ }^{29}$

For the traditional sparkling wine, the following results were obtained for brut sparkling wine (i) total dry extract, 26.8-35.7 $\mathrm{g} \mathrm{L}^{-1}$ : reduced dry extract, 18.40-22.40 $\mathrm{g} \mathrm{L}^{-1}$; and total sugar content, 7.98-15.00 $\mathrm{g} \mathrm{L}^{-1}$ and for demi-sec sparkling wine (ii) total dry extract, $47.5-65.7 \mathrm{~g} \mathrm{~L}^{-1}$; reduced dry extract, $18.86-23.47 \mathrm{~g} \mathrm{~L}^{-1}$; and total sugar content, 25.75-47.84 $\mathrm{g} \mathrm{L}^{-1}$. These parameters could be influenced by chaptalization, which is a common practice in order to 
Table 3. The physicochemical analysis of sparkling wines

\begin{tabular}{|c|c|c|c|c|c|c|c|c|c|}
\hline $\begin{array}{l}\text { Sample } \\
\text { (ID) }\end{array}$ & $\begin{array}{c}\text { Pressure } \\
\left(20^{\circ} \mathrm{C}\right) / \\
\text { atm }\end{array}$ & $\begin{array}{l}\text { Density / } \\
\left(\mathrm{g} \mathrm{cm}^{-3}\right)\end{array}$ & $\begin{array}{c}\text { Alcoholic } \\
\text { grade / } \\
(\%, \mathrm{v} / \mathrm{v})\end{array}$ & $\begin{array}{c}\text { Total dry } \\
\text { extract / } \\
\left(\mathrm{g} \mathrm{L}^{-1}\right)\end{array}$ & $\begin{array}{c}\text { Reduced dry } \\
\text { extract / } \\
\left(\mathrm{g} \mathrm{L}^{-1}\right) \\
\end{array}$ & $\begin{array}{c}\text { Total sugar } \\
\text { content / } \\
\left(\mathrm{g} \mathrm{L}^{-1}\right)\end{array}$ & $\mathrm{pH}$ & $\begin{array}{c}\text { Total } \\
\text { acidity / } \\
\left(\mathrm{m}_{\mathrm{eq}} \mathrm{L}^{-1}\right)\end{array}$ & $\begin{array}{c}\text { Sulfur } \\
\text { dioxide / } \\
\left(\mathrm{mg} \mathrm{L}^{-1}\right)\end{array}$ \\
\hline 1 & 5.6 & 1.029 & 7.5 & 106.0 & 33.00 & 74.00 & 3.22 & 102.4 & 129.1 \\
\hline 2 & 5.7 & 1.021 & 7.7 & 86.5 & NA & 60.13 & 2.95 & 121.8 & 88.0 \\
\hline 3 & 7.1 & 1.023 & 7.8 & 93.0 & 23.22 & 70.78 & 2.98 & 91.1 & 74.9 \\
\hline 4 & 5.1 & 1.022 & 7.5 & 88.6 & 23.08 & 66.52 & 3.35 & 87.5 & 136.2 \\
\hline 5 & 5.8 & 1.020 & 7.0 & 81.6 & 20.30 & 62.30 & 3.13 & 94.9 & 72.8 \\
\hline 6 & 7.8 & 1.020 & 7.8 & 84.2 & 25.34 & 59.86 & 3.16 & 103.9 & 33.9 \\
\hline 7 & 4.8 & 1.025 & 7.8 & 96.7 & 24.33 & 73.38 & 3.06 & 108.8 & 151.4 \\
\hline 8 & 7.2 & 1.024 & 7.4 & 94.6 & 27.88 & 67.72 & 2.96 & 135.7 & 159.7 \\
\hline 9 & 7.3 & 1.023 & 7.7 & 92.8 & 25.99 & 67.81 & 3.12 & 101.4 & 154.6 \\
\hline 10 & 6.7 & 1.020 & 7.6 & 84.2 & 22.97 & 62.23 & 3.20 & 93.9 & 108.2 \\
\hline 11 & 5.2 & 1.023 & 7.4 & 89.9 & 19.18 & 71.72 & 3.10 & 96.4 & 149.4 \\
\hline 12 & 6.9 & 1.025 & 7.9 & 96.4 & 28.53 & 68.88 & 3.35 & 95.9 & 234.2 \\
\hline 13 & 6.4 & 1.022 & 7.6 & 88.1 & 24.98 & 64.13 & 3.08 & 100.9 & 139.8 \\
\hline 14 & 6.3 & 1.028 & 8.0 & 107.1 & 33.35 & 74.75 & 3.50 & 99.9 & 47.4 \\
\hline 15 & 3.9 & 1.027 & 7.6 & 101.6 & 28.60 & 74.00 & 3.44 & 91.9 & 85.9 \\
\hline 16 & 5.0 & 1.025 & 8.5 & 99.0 & NA & 66.09 & 3.54 & 98.4 & 67.8 \\
\hline 17 & 5.8 & 1.023 & 7.5 & 91.0 & 24.79 & 67.21 & 3.03 & 103.4 & 115.5 \\
\hline 18 & 5.1 & 1.020 & 9.0 & 87.8 & 28.90 & 59.90 & 3.25 & 94.9 & 107.5 \\
\hline 19 & 5.7 & 1.026 & 7.7 & 100.3 & 28.41 & 72.89 & 3.14 & 83.5 & 144.3 \\
\hline 20 & 5.6 & 1.025 & 8.0 & 101.4 & 36.56 & 65.84 & 3.15 & 94.4 & 136.3 \\
\hline 21 & 4.9 & 0.993 & 12.3 & 29.4 & 22.40 & 8.00 & 3.35 & 83.5 & 146.9 \\
\hline 22 & 5.1 & 1.001 & 11.7 & 47.5 & 22.75 & 25.75 & 3.32 & 94.4 & 156.8 \\
\hline 23 & 5.2 & 0.997 & 11.5 & 35.7 & 21.70 & 15.00 & 3.37 & 92.4 & 162.6 \\
\hline 24 & 4.3 & 1.003 & 11.2 & 51.7 & 21.08 & 31.63 & 3.26 & 86.5 & 131.2 \\
\hline 25 & 4.7 & 0.995 & 11.4 & 30.2 & 19.43 & 11.78 & 3.24 & 84.0 & 115.2 \\
\hline 26 & 5.7 & 0.993 & 11.9 & 26.8 & 18.85 & 8.95 & 3.14 & 95.2 & 113.6 \\
\hline 27 & 4.6 & 0.994 & 12.0 & 28.7 & 19.54 & 10.16 & 3.05 & 90.5 & 97.9 \\
\hline 28 & 4.7 & 0.996 & 11.2 & 31.8 & 21.35 & 11.45 & 3.24 & 89.7 & 108.5 \\
\hline 29 & 4.8 & 1.004 & 11.3 & 55.1 & 23.47 & 32.63 & 3.44 & 83.0 & 292.5 \\
\hline 30 & 3.3 & 1.008 & 10.6 & 60.8 & NA & 39.70 & 3.46 & 65.4 & 61.4 \\
\hline 31 & 5.3 & 1.003 & 11.7 & 52.2 & 21.37 & 31.83 & 3.54 & 94.4 & 143.4 \\
\hline 32 & 5.6 & 0.994 & 12.3 & 31.8 & 19.58 & 13.22 & 3.37 & 86.0 & 111.7 \\
\hline 33 & 4.3 & 0.995 & 12.3 & 32.6 & 21.68 & 11.92 & 3.30 & 89.5 & 101.1 \\
\hline 34 & 6.3 & NA & 11.7 & 28.9 & NA & 7.98 & 3.23 & 82.3 & 48.0 \\
\hline 35 & 5.6 & 0.994 & 11.7 & 29.4 & 18.40 & 12.00 & 3.35 & 73.1 & 97.9 \\
\hline 36 & 5.2 & 1.008 & 11.4 & 65.7 & 18.86 & 47.84 & 3.34 & 65.1 & 97.4 \\
\hline
\end{tabular}

NA: not analyzed.

increase the final alcohol content by addition of cane or beet sugar.

The $\mathrm{pH}$ of sparkling wine is around 3.2, within the titratable acidity, and plays an important role in the quality of the product. ${ }^{8}$ The flavor and acceptance of the wine has been connected with the acidity of the medium and is directly related to the release of volatile compounds responsible for the pleasant odor of wine. ${ }^{40}$

The main compounds contributing to the acidity of wine are citric, malic, and tartaric acids which are derived from 
grapes as photosynthesis metabolites. ${ }^{41}$ Maintaining the $\mathrm{pH}$ around 3 and 4 , the storage temperature at ca. $15{ }^{\circ} \mathrm{C}$ and alcohol strength at $12 \%(\mathrm{v} / \mathrm{v})$, allows an adequate evolution of the wine during the ageing time with an adequate rate of natural autolysis. ${ }^{8,42}$

The autolysis of the yeast is a slow process related to cell death that occurs during the ageing after prolonged contact with the sparkling wine. Among other compounds, terpenic alcohols, higher alcohols, peptides, fatty acids, nucleotides and amino acids are released in the medium and have an important role and the final characteristics of the wine composition, foam properties and organoleptic perception of the sparkling wine. ${ }^{42}$

The following results were obtained for the Moscatel sparkling wine: total acidity, 87.5-135.7 $\mathrm{m}_{\mathrm{eq}} \mathrm{L}^{-1}$; $\mathrm{pH}$ 2.95-3.54. For the traditional sparkling wine, the total acidity was 65.1-95.2 $\mathrm{m}_{\mathrm{eq}} \mathrm{L}^{-1}$ and the $\mathrm{pH}$ was 3.05-3.54.

\section{Results of the gas chromatography analysis}

The volatile profile assessment was carried out in order to evaluate the characteristics of each product and verify if the values obtained are according to the identity and quality standards set by the MAPA and if the wines are suitable for commercialization in the Brazilian market. All the sparkling wine evaluated were within a normal range of expected characteristics according to the quality standards for each product class and the results are shown in Table 4.

In sparkling wine, the effervescence caused by the diffusion of $\mathrm{CO}_{2}$ helps to enhance the perception of the organoleptic characteristics of the products and is directly influenced by the nucleation and frequency of bubble escape, the growth rate of rising bubbles, among others. ${ }^{1}$

The organoleptic characteristics of a wine are results of a complex mixture of compounds where the terpenes and terpenoids come from the grapes, aliphatic alcohols, ethers, acids and aldehydes are produced during the fermentation process and autolysis of yeasts during ageing produces other compounds such as esters. ${ }^{43}$ During the ageing time, a change in the volatile profile of the wine was found wherein an increase of most of the ethyl esters and the decrease in the acetaldehyde concentration was observed. ${ }^{44}$

Most of the alcoholic content in wine is composed of ethanol; however, methanol and higher alcohols are typically present. ${ }^{45}$ The higher alcohols are composed by compounds with at least three carbons and the higher alcohol and the contents of 2-butanol (sec-butanol), 1-butanol, undergo from the oxidative ageing of wine, while the 1-propanol, 2-methylpropan-1-ol (isobutanol), 2-methyl-1-butanol and 3-methyl-1-butanol (isoamyl alcohol) are released during the fermentation/autolysis step as by-products and secondary metabolites..$^{4-47}$

Some higher alcohols are also produced from amino acids through biochemical pathways and this content could be associated with geographical and botanical origin. ${ }^{48,49}$ The 3-methyl-1-butanol (isoamyl alcohol) and 2-methyl1-butanol (active amyl alcohol) are produced biochemically from the amino acids leucine and isoleucine, respectively, while the 2-methylpropan-1-ol is derived from valine. ${ }^{37}$

From the results, is possible to conclude: (i) the methanol content in all samples is lower than the limit established by OIV $\left(<250 \mathrm{mg} \mathrm{L}^{-1}\right)$; $($ ii) there is no significant occurrence of oxidative ageing due the absence of the $n$-butanol and sec-butanol and (iii) there are variable amounts of $n$-propanol, isobutanol, 2-methyl-1-butanol and isoamyl alcohol contents, which are related to the fermentative process, secondary metabolic routes and ageing of the product. This behavior is expected due the difference in the ageing times and the grape varieties used for vinification of traditional sparkling wine and Moscatel sparkling wine.

\section{Results of the isotopic analysis}

The isotopic analysis was carried out in order to evaluate the isotopic signature of the $\delta^{13} \mathrm{C}$ of $\mathrm{CO}_{2}$ from the headspace of the sample bottles. For the first time, this kind of assessment was requested by MAPA in Rio Grande do Sul in order to evaluate the quality and characteristics of local products and to implement the isotopic analysis approach into standard quality control procedures.

The technique of using stable isotope ratios is based on the fact that natural products have significant differences in their isotope content that is dependent on botanical variety, and geographical origin, among others. ${ }^{14}$

Inside the $0.75 \mathrm{~L}$ sparkling wine bottles are approximately five liters of $\mathrm{CO}_{2}$ that, as soon as the bottle are uncorked, progressively releases the gas dissolved into the wine and is responsible for the effervescence process. ${ }^{50}$ $\mathrm{CO}_{2}$ bubbles in sparkling beverages may come from natural sugar fermentation produced in situ (in bottle) or ex situ (out-of-bottle), or from exogenous carbonation by adding pressurized $\mathrm{CO}_{2} \cdot{ }^{12}$

The equilibrium established between the dissolved $\mathrm{CO}_{2}$ and the gas phase inside the bottle follows Henry's law, which is influenced mainly by the pressure and the temperature of the sparkling wine. As the $\mathrm{pH}$ of the sparkling wine nears $\mathrm{pH} 3$, no carbonated species $\left(\mathrm{CO}_{3}{ }^{2-}\right.$ and $\left.\mathrm{HCO}_{3}{ }^{-}\right)$ should coexist with dissolved $\mathrm{CO}_{2}$ and it is not expected any significant isotopic fractionation..$^{50}$ The results of the isotopic ratios of the $\delta^{13} \mathrm{C}_{\text {of }} \mathrm{CO}_{2}$ from the headspace of bottles could be found as Supplementary Information section (Table S2). 
Table 4. Gas chromatographic analysis of sparkling wine

\begin{tabular}{|c|c|c|c|c|c|c|c|c|}
\hline $\begin{array}{l}\text { Sample } \\
\text { (ID) }\end{array}$ & $\begin{array}{l}\text { Acetaldehyde / } \\
\left(\mathrm{mg} \mathrm{L}^{-1}\right)\end{array}$ & $\begin{array}{l}\text { Ethyl acetate / } \\
\left(\mathrm{mg} \mathrm{L}^{-1}\right)\end{array}$ & $\begin{array}{l}\text { Methanol / } \\
\left(\mathrm{mg} \mathrm{L}^{-1}\right)\end{array}$ & $\begin{array}{c}n \text {-Propanol / } \\
\left(\mathrm{mg} \mathrm{L}^{-1}\right)\end{array}$ & $\begin{array}{l}\text { Isobutanol / } \\
\left(\mathrm{mg} \mathrm{L}^{-1}\right)\end{array}$ & $\begin{array}{c}\text { 2-Methyl- } \\
\text { 1-butanol / } \\
\left(\mathrm{mg} \mathrm{L}^{-1}\right)\end{array}$ & $\begin{array}{l}\text { Isoamyl } \\
\text { alcohol / } \\
\left(\mathrm{mg} \mathrm{L}^{-1}\right)\end{array}$ & $\begin{array}{c}\Sigma \text {-Higher } \\
\text { alcohol / } \\
\left(\mathrm{mg} \mathrm{L}^{-1}\right)\end{array}$ \\
\hline 1 & 41.6 & 12.7 & 61.2 & 19.0 & 12.3 & NQ & 57.9 & 89.3 \\
\hline 2 & 25.5 & 18.3 & 36.7 & 30.1 & 7.8 & NQ & 35.4 & 73.4 \\
\hline 3 & 43.2 & 24.7 & 29.7 & 22.2 & 14.3 & 16.1 & 86.9 & 139.5 \\
\hline 4 & 59.8 & 33.3 & 52.0 & 22.1 & 14.7 & NQ & 53.3 & 90.0 \\
\hline 5 & 53.1 & 16.1 & 33.9 & 15.9 & 7.6 & NQ & 37.6 & 61.1 \\
\hline 6 & 23.5 & 45.2 & 36.3 & 43.8 & 33.0 & NQ & 44.5 & 121.4 \\
\hline 7 & 72.7 & 15.7 & 40.9 & 37.9 & 9.6 & NQ & 46.2 & 93.6 \\
\hline 8 & 60.2 & 15.9 & 19.5 & 14.7 & 8.9 & NQ & 59.2 & 82.8 \\
\hline 9 & 55.2 & 18.2 & 51.8 & 28.7 & 8.9 & NQ & 49.5 & 87.1 \\
\hline 10 & 41.0 & 13.5 & 61.7 & 30.6 & 5.8 & NQ & 56.6 & 93.0 \\
\hline 11 & 83.1 & 10.9 & 61.0 & 25.2 & 5.4 & NQ & 32.8 & 63.3 \\
\hline 12 & 99.1 & 17.6 & 73.4 & 19.6 & 21.0 & NQ & 55.1 & 95.7 \\
\hline 13 & 45.4 & 16.8 & 35.1 & 26.9 & 7.0 & NQ & 42.9 & 76.8 \\
\hline 14 & 33.8 & 26.4 & 63.3 & 10.9 & 9.9 & NQ & 24.6 & 45.4 \\
\hline 15 & 37.7 & 16.0 & 49.8 & 18.8 & 8.8 & NQ & 37.0 & 64.7 \\
\hline 16 & 27.1 & 21.4 & 79.9 & 13.2 & 13.7 & NQ & 32.0 & 58.9 \\
\hline 17 & 57.2 & 25.5 & 21.5 & 25.6 & 5.3 & NQ & 46.1 & 76.9 \\
\hline 18 & 69.0 & 27.9 & 37.6 & 24.6 & 16.9 & 19.0 & 101.0 & 161.5 \\
\hline 19 & 98.0 & 29.3 & 40.2 & 32.2 & 8.1 & NQ & 46.8 & 87.1 \\
\hline 20 & 64.1 & 20.7 & 45.9 & 32.0 & 9.1 & NQ & 47.1 & 88.1 \\
\hline 21 & 72.7 & 16.9 & 48.5 & 27.6 & 24.2 & 19.9 & 101.3 & 173.0 \\
\hline 22 & 70.3 & 20.6 & 53.9 & 39.0 & 30.2 & 22.1 & 117.5 & 208.8 \\
\hline 23 & 73.3 & 13.1 & 44.8 & 31.4 & 23.7 & 22.1 & 110.1 & 187.3 \\
\hline 24 & 62.2 & 17.1 & 66.1 & 47.1 & 22.4 & 22.8 & 113.6 & 205.9 \\
\hline 25 & 68.4 & 19.9 & 67.3 & 47.8 & 22.2 & 23.2 & 116.1 & 209.4 \\
\hline 26 & 56.6 & 44.4 & 25.0 & 53.7 & 17.2 & NQ & 76.4 & 147.3 \\
\hline 27 & 67.0 & 37.7 & 26.9 & 31.1 & 18.2 & 24.8 & 116.7 & 190.8 \\
\hline 28 & 70.7 & 22.5 & 39.4 & 28.6 & 29.4 & NQ & 71.1 & 129.1 \\
\hline 29 & 118.9 & 8.0 & 23.9 & 37.4 & 17.2 & 18.8 & 93.2 & 166.5 \\
\hline 30 & 30.5 & 30.0 & 84.8 & 28.7 & 29.0 & 38.1 & 149.8 & 245.6 \\
\hline 31 & 78.7 & 25.8 & 28.6 & 71.9 & 25.9 & NQ & 69.2 & 167.0 \\
\hline 32 & 69.2 & 32.6 & 39.0 & 54.0 & 16.3 & NQ & 84.0 & 154.4 \\
\hline 33 & 53.3 & 13.2 & 21.9 & 38.4 & 16.3 & 17.8 & 97.2 & 169.7 \\
\hline 34 & 24.2 & 15.5 & 45.3 & 30.1 & 19.8 & 23.1 & 119.8 & 192.8 \\
\hline 35 & 58.3 & 32.6 & 51.0 & 51.5 & 32.2 & 30.6 & 160.2 & 274.5 \\
\hline 36 & 55.4 & 31.5 & 45.8 & 50.1 & 32.8 & 30.5 & 164.6 & 278.0 \\
\hline
\end{tabular}

ND: not detected; NQ: not quantified.

The main factor that influences the ${ }^{13} \mathrm{C}$ content in plants is the photosynthetic cycle used. The $\mathrm{C} 3$ pathway (Calvin plants, such as vines) generates $\delta^{13} \mathrm{C}$ isotope ratios ranging from -22 to $-28 \%$ o whereas the $\mathrm{C} 4$ pathway (Hatch-Slack plants, such as cane and maize) have enriched $\delta^{13} \mathrm{C}$ isotope ratio values ranging from -10 to $-14 \% .^{51}$
From the results, it is possible to identify great heterogeneity in the carbon isotope ratio between the samples, especially in the $\delta^{13} \mathrm{C}-\mathrm{CO}_{2}$ of the traditional sparkling wine. In order to better visualize the $\delta^{13} \mathrm{C}$ samples profile, the data structure are plotted in Figure 2.

A large range of isotopic signatures is found in the 
products. The $\delta^{13} \mathrm{C}-\mathrm{CO}_{2}$ of the traditional sparkling wine ranged from -9.257 to $-26.391 \%$ with almost the samples presenting an isotopic signature representative of $\mathrm{CO}_{2}$ derived from fermentation of sugar from $\mathrm{C} 4$ plants.

Already the Moscatel sparkling wine presented ${ }^{13} \mathrm{C}_{-} \mathrm{CO}_{2}$ isotopic values between -16.664 to $-23.688 \%$ o. Even with the expected slight differences associated with Oenological factors as genetic variety and temperature/rainfall during the cultivation step, ${ }^{52,53}$ the Moscatel $\delta^{13} \mathrm{C}-\mathrm{CO}_{2}$ values are richer in ${ }^{13} \mathrm{C}$ compared to the genuine Italian Asti $(-25.7 \%),{ }^{18}$ which could be resulted from the addition of exogenous $\mathrm{C} 4$ sugar. In Table 5, the isotopic values of the samples were associated with their probable source.

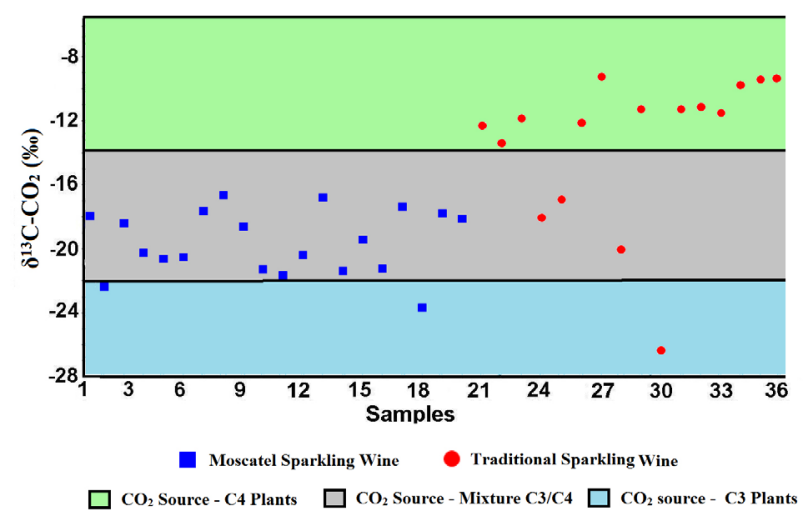

Figure 2. The $\delta^{13} \mathrm{C}-\mathrm{CO}_{2}$ data structure of the sparkling wine samples.
The isotope ratio data are very effective in identifying the probable sugar feedstock that generated the free and dissolved $\mathrm{CO}_{2}$, however, only using the $\delta^{13} \mathrm{C}^{-} \mathrm{CO}_{2}$, it was not possible to identify classes and fermentative processes.

\section{Exploratory analysis}

The PCA is a descriptive multivariate projection technique based on a linear combination of variables to obtain the principal components (PCs) which are used to extract the maximum of information from the data set. ${ }^{54}$ The exploratory analysis was applied to three data combination, which was: $(i)$ isotope analysis with the physicochemical data; (ii) isotope analysis with the volatile profile and (iii) all the data.

\section{Combined data from $\delta^{13} \mathrm{C}-\mathrm{CO}_{2}$ and physicochemical analysis}

The PCA was applied for the exploratory analysis of the sparkling wine samples from the combination of the physicochemical data with the $\delta^{3} \mathrm{C}-\mathrm{CO}_{2}$ analysis.

Before the multivariate procedure, all the variables that showed more than $30 \%$ of missing values were excluded from the analysis. For the other parameters, the PCA algorithm was used to complete the data gaps and a specific fill missing procedure are performed to each sparkling wine

Table 5. Source of the $\mathrm{CO}_{2}$ from the bottle headspace

\begin{tabular}{|c|c|c|c|c|c|}
\hline Sample (ID) & Class & $\mathrm{CO}_{2}$ source $^{\mathrm{a}}$ & Sample (ID) & Class & $\mathrm{CO}_{2}$ source $^{\mathrm{a}}$ \\
\hline 1 & Moscatel sparkling wine & mixture $(\mathrm{C} 3 / \mathrm{C} 4)$ & 19 & Moscatel sparkling wine & mixture $(\mathrm{C} 3 / \mathrm{C} 4)$ \\
\hline 2 & Moscatel sparkling wine & mixture (C3/C4) & 20 & Moscatel sparkling wine & mixture $(\mathrm{C} 3 / \mathrm{C} 4)$ \\
\hline 3 & Moscatel sparkling wine & mixture (C3/C4) & 21 & sparkling wine & $\mathrm{C} 4$ \\
\hline 4 & Moscatel sparkling wine & mixture $(\mathrm{C} 3 / \mathrm{C} 4)$ & 22 & sparkling wine & $\mathrm{C} 4$ \\
\hline 5 & Moscatel sparkling wine & mixture $(\mathrm{C} 3 / \mathrm{C} 4)$ & 23 & sparkling wine & $\mathrm{C} 4$ \\
\hline 6 & Moscatel sparkling wine & mixture (C3/C4) & 24 & sparkling wine & mixture $(\mathrm{C} 3 / \mathrm{C} 4)$ \\
\hline 7 & Moscatel sparkling wine & mixture (C3/C4) & 25 & sparkling wine & mixture $(\mathrm{C} 3 / \mathrm{C} 4)$ \\
\hline 8 & Moscatel sparkling wine & mixture $(\mathrm{C} 3 / \mathrm{C} 4)$ & 26 & sparkling wine & $\mathrm{C} 4$ \\
\hline 9 & Moscatel sparkling wine & mixture $(\mathrm{C} 3 / \mathrm{C} 4)$ & 27 & sparkling wine & $\mathrm{C} 4$ \\
\hline 10 & Moscatel sparkling wine & mixture (C3/C4) & 28 & sparkling wine & mixture $(\mathrm{C} 3 / \mathrm{C} 4)$ \\
\hline 11 & Moscatel sparkling wine & mixture (C3/C4) & 29 & sparkling wine & $\mathrm{C} 4$ \\
\hline 12 & Moscatel sparkling wine & mixture (C3/C4) & 30 & sparkling wine & $\mathrm{C} 3$ \\
\hline 13 & Moscatel sparkling wine & mixture $(\mathrm{C} 3 / \mathrm{C} 4)$ & 31 & sparkling wine & $\mathrm{C} 4$ \\
\hline 14 & Moscatel sparkling wine & mixture (C3/C4) & 32 & sparkling wine & $\mathrm{C} 4$ \\
\hline 15 & Moscatel sparkling wine & mixture (C3/C4) & 33 & sparkling wine & $\mathrm{C} 4$ \\
\hline 16 & Moscatel sparkling wine & mixture (C3/C4) & 34 & sparkling wine & $\mathrm{C} 4$ \\
\hline 17 & Moscatel sparkling wine & mixture (C3/C4) & 35 & sparkling wine & $\mathrm{C} 4$ \\
\hline 18 & Moscatel sparkling wine & mixture (C3/C4) & 36 & sparkling wine & $\mathrm{C} 4$ \\
\hline
\end{tabular}

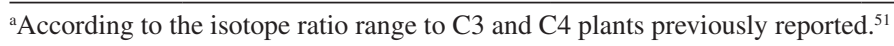


class (traditional and Moscatel). Prior the application of the chemometric procedure, the data were scaled and the fill missing data were performed by using the optimal number of principal components for each sparkling wine class.

For the PCA analysis, the data were mean-centered, scaled by dividing by their respective standard deviation (A/standard deviation), without rotation, cross-validation and using the NIPALS algorithm. The results of the PCA are shown in Figure 3, while the specific PCA model, developed for each sparkling wine class, are presented in the Supplementary Information section Figure S2.
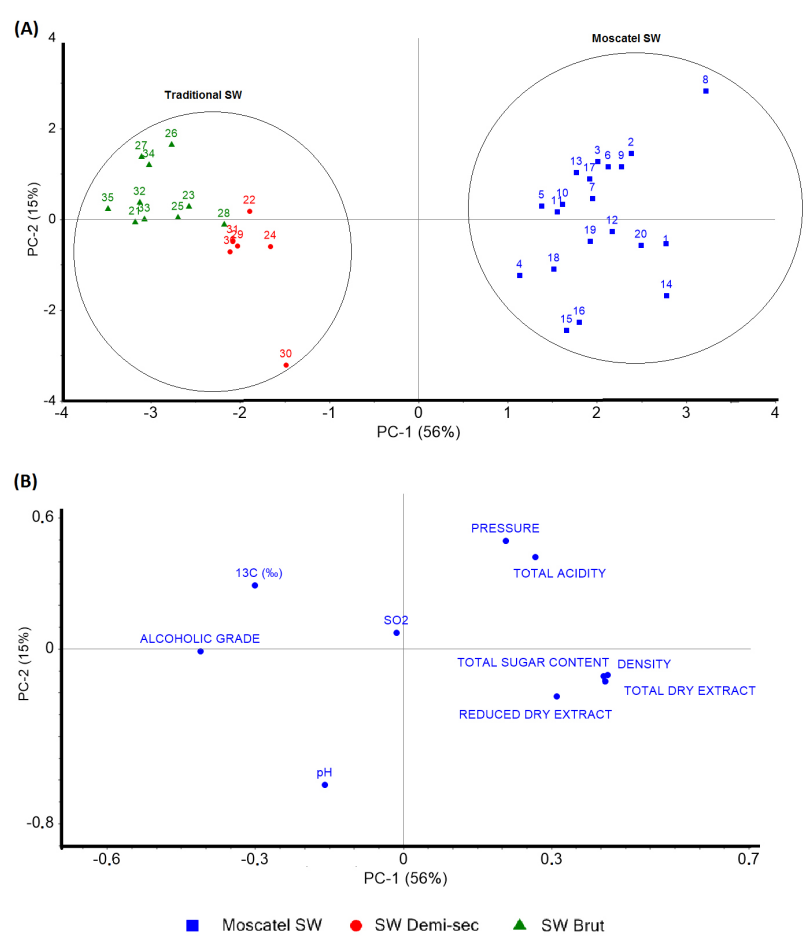

Figure 3. PCA of the combined data from $\delta^{13} \mathrm{C}-\mathrm{CO}_{2}$ and physicochemical analysis: (A) scores and (B) loading.

After obtaining the PCA score plot results, it was possible to project graphically the properties of the analyzed samples. From these results, it is concluded that is possible to separate the types of sparkling wine. As shown in Figure 3A, three sparkling wine groups, corresponding to: (i) Moscatel (blue squares), (ii) traditional brut (green triangles) and (iii) traditional demi-sec (red dots) are clearly distinguished.

From the loadings of PCA (Figure 3B) it is observed the correlation between the modeled variables. The Moscatel samples are positioned in the positive values of $\mathrm{X}$-axis (PC1) and are associated with higher density, total sugar content and total/reduced dry extract, while the traditional sparkling wines, positioned in the negative values of $\mathrm{X}$-axis, are mainly characterized by the higher alcoholic content and enriched $\delta^{13} \mathrm{C}-\mathrm{CO}_{2}$.
The PC1, which take $56 \%$ of the explained variance of the model, are especially important to discrimination of the groups. The identification of the vinification style (Moscatel and traditional) could be easily carried through the variables density, total dry extract, reduced dry extract, total sugar content and $\delta^{13} \mathrm{C}-\mathrm{CO}_{2}$, with higher PC1 loading. Besides these variables, the discrimination between the traditional sparkling wine (brut and demi-sec samples) also found significant differences in the parameters pressure and total acidity (Figure S3).

It is possible to observe that the parameters density, total dry extract, reduced dry extract and total sugar content are naturally highly correlated and are inversely related to the alcoholic grade. The $\delta^{13} \mathrm{C}-\mathrm{CO}_{2}$ and total sugar content appear to be inversely correlated at same time that are directly correlated with the alcoholic grade, meaning that $\mathrm{C} 4$ sugar have been used to generate de $\mathrm{CO}_{2}$ of the beverage and also increase the alcohol content of the beverages.

The PC2, which take $15 \%$ of the explained variance, are mainly influenced by the variables pressure, total acidity, $\mathrm{pH}$ and reduced dry extract. For these variables, it can be seen in the loading chart, that the $\mathrm{pH}$ and total acidity are naturally inversely correlated. At the same time, the $\mathrm{CO}_{2}$ pressure is directly related to the total acidity and both variables are inversely related to the reduced dry extract. According this behavior (Figure S2) it is supposed that malolactic fermentation occurs in some samples, which results in the decreasing in the reduced dry extract, followed by spoilage by microorganisms, which increases the volatile acidity and the bottle pressure..$^{55}$

Combined data from $\delta^{13} \mathrm{C}-\mathrm{CO}_{2}$ and gas chromatography analysis

The PCA was applied for the exploratory analysis of the sparkling wine samples from the combination of the volatile profile with the $\delta^{13} \mathrm{C}-\mathrm{CO}_{2}$ analysis. Before the chemometrics procedure, all the variables that present more than $30 \%$ of missing values were excluded from the chemometrics analysis. For this data set, the 2-methyl1-butanol (> 30\% of missing data) are excluded from the multivariate analysis and no fill missing data procedure are required for the other variables.

For the PCA analysis, the data were mean centered, scaled by dividing by their respective standard deviation (A/standard deviation), without rotation, cross-validation and using the NIPALS algorithm and the results are shown in Figure 4.

From Figure 4A, it can be seen that is possible to separate the type of sparkling wine into two clusters 

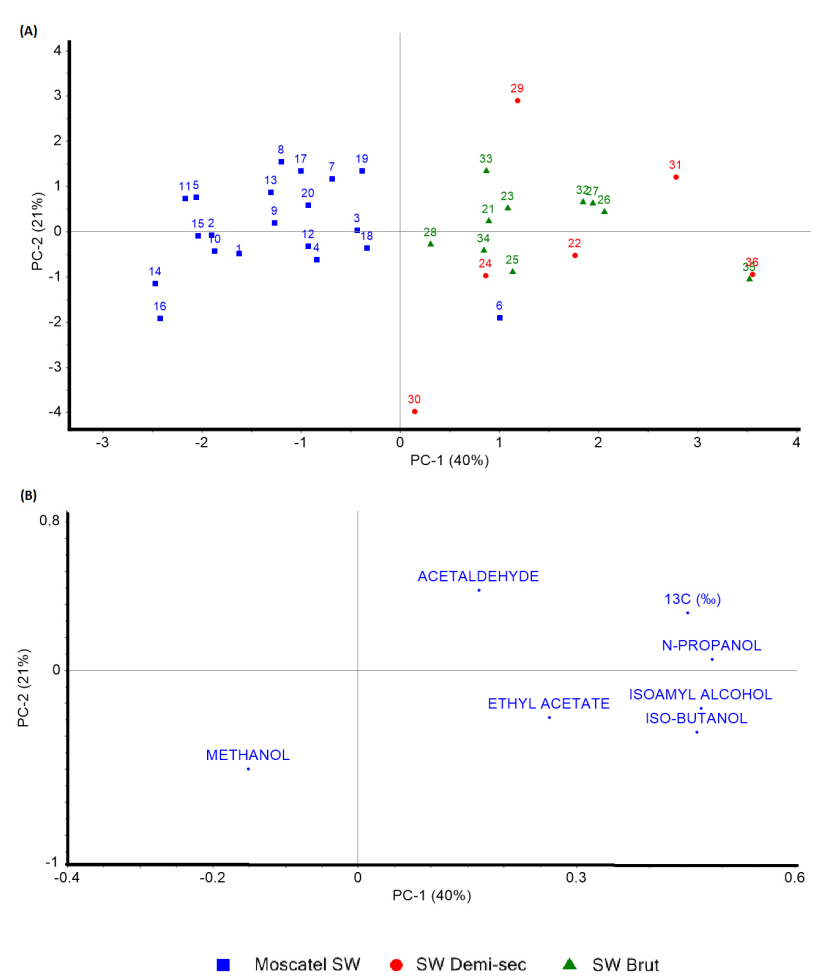

Figure 4. PCA apply to the combined data from $\delta^{13} \mathrm{C}-\mathrm{CO}_{2}$ and chromatography analysis: (A) scores and (B) loading.

corresponding to traditional sparkling wine (brut-green triangles and demi-sec-red dots) and Moscatel sparkling wine (blue box), while the loading graph (Figure 4B) identify the main characteristics of the samples.

The PC1, which take $40 \%$ of the explained variance of the model, are especially important to discrimination of the groups. The Moscatel sample, observed in the negative scores values of PC1, presents higher values of methanol. Since the methanol is not produced during the yeast fermentation step, these could be associated with the must sanitation and difference in the grape variety and grape pectin content.

The traditional sparkling wine, presenting enriched $\delta^{13} \mathrm{C}^{-} \mathrm{CO}_{2}$ and elevated content of ethyl acetate, acetaldehyde, $n$-propanol, isobutanol and isoamyl alcohol, are observed in the positive values of $\mathrm{X}$-axis (PC1) of score graph. Since they are all by-products and secondary metabolites of yeast, the elevated contents of these volatile compounds, associated with the traditional sparkling wine, and their high correlation, could be explained by the long ageing time and difference in the grape variety that are employed. ${ }^{44-49}$

In this work, it was found a great correlation of enriched $\delta^{13} \mathrm{C}^{-} \mathrm{CO}_{2}$ with $n$-propanol, isobutanol and isoamyl alcohol content and, in a minor degree, with ethyl acetate and acetaldehyde. As previously reported by the Nisbet et al., ${ }^{56}$ many of the carbons of the volatiles compounds came from the hexoses metabolism, and the directly correlation of heavier $\delta^{13} \mathrm{C}-\mathrm{CO}_{2}$ with these variables, could demonstrate some increase of these compound resulting from the fermentation of the $\mathrm{C} 4$ sugar.

The PC2 (21\% of the explained variance) and the PC3 (16\% of the explained variance) are mainly influenced by the acetaldehyde and ethyl acetate content. Higher quantity of these compounds are expected to be found in the more alcoholic traditional sparkling wines samples. Since the acetaldehyde, produced along the early stage of fermentation, is a precursor of the ethyl acetate, produced along the fermentation step and ageing time, these variables are inversely related in the loading graph of PC2 and PC3.

\section{Combined data from $\delta^{13} \mathrm{C}-\mathrm{CO}_{2}$, physicochemical and} chromatography analysis

In order to evaluate the viability to combine all variables (physicochemical, gas chromatography and stable carbon isotope analysis) the PCA was applied to perform the exploratory analysis of these data. The data were treated as previous discussed and the results of the PCA are shown in Figure S4.

The arrangement of the sample is very similar to the score graph of the PCA from the combination of $\delta^{13} \mathrm{C}-\mathrm{CO}_{2}$ with physicochemical parameters (Figure 3A), however, it is no longer possible to distinguish in the traditional sparkling wine cluster the separation between the brut and demi-sec samples. This means that, although there is the capability to separate the Moscatel from the traditional sparkling wine based on the physicochemical and $\delta^{13} \mathrm{C}_{-}-\mathrm{CO}_{2}$ parameters, the homogeneity of the volatile profile in the traditional sparkling wine samples lead to loss of the resolution needed to subdivide their cluster.

\section{Conclusions}

This work focused on the application of chemometric tool in a combined data approach for chemical characterization of sparkling wines through physicochemical, gas chromatography and stable carbon isotope analysis.

From the PCA, it was observed that it is possible to discriminate and classify the samples as belonging to the wine groups using the measured parameters. From the physicochemical data is possible to clearly identify the classes (Moscatel, traditional brut and traditional demi-sec) while the volatile profile only lead to discriminate between the traditional and Moscatel samples.

Also, it is possible to identify great heterogeneity in the carbon isotope ratio between the samples, especially in the $\delta^{13} \mathrm{C}-\mathrm{CO}_{2}$ of the traditional sparkling wine. This profile confirm that the isotopic signature of the $\mathrm{CO}_{2}$ could be derived from the fermentation of sugar from 
C4 plants and that this addition could be carried out with different purposes. Through the combined data approach, it is possible to better understand the relation between the variables and conclude that the $\mathrm{C} 4$ sugar addition was used for objectives such as sweetening, $\mathrm{CO}_{2}$ production, and increasing the alcoholic strength of the beverage.

With the increasing production of sparkling wines in Brazil and the small amount of research dedicated to the local sparkling wine, this work helps to evaluate the standards of the sparkling wines from the Rio Grande do Sul. Therefore, futures works could be carried by the Ministry of Agriculture, Livestock and Supply of the Rio Grande do Sul for quality control purpose.

\section{Supplementary Information}

Supplementary information is available free of charge at http://jbcs.sbq.org.br as PDF file.

\section{Acknowledgments}

The authors thank the Institute of Petroleum and Natural Resources-IPR of the Pontifical Catholic University of Rio Grande do Sul for the infrastructure, to the Ministry of Agriculture, Livestock and Supply of the Rio Grande do Sul for the support and knowledge sharing and to the National Counsel of Technological and Scientific DevelopmentCNPq-for the research scholarships.

\section{References}

1. Liger-Belair, G.; Polidori, G.; Zéninari, V.; Anal. Chim. Acta 2012, 732, 1.

2. Aurand, J. M.; OIV's Focus: The Sparkling Wine Market; $37^{\text {th }}$ OIV World Congress of Vine and Wine: Mendoza, Argentina, 2014.

3. Stefenon, C. A.; Bonesi, C. D. M.; Marzarotto, V.; Barnabé, D.; Spinelli, F. R.; Webber, V.; Vanderlinde, R.; Food Chem. 2014, 145, 292.

4. Aurand, J. M.; State of the Vitiviniculture World Market; $38^{\text {th }}$ OIV World Congress of Vine and Wine: Mainz, Germany, 2015.

5. Dutra, S. V.; Adami, L.; Marcon, A. R.; Carnieli, G. J.; Roani, C. A.; Spinelli, F. R.; Leonardelli, S.; Vanderlinde, R.; Food Chem. 2013, 141, 2148.

6. Soares, R. D.; Welke, J. E.; Nicolli, K. P.; Zanus, M.; Caramão, E. B.; Manfroi, V.; Zini, C. A.; Food Chem. 2015, 183, 291.

7. Nicolli, K. P.; Welke, J. E.; Closs, M.; Caramão, E. B.; Costa, G.; Manfroi, V.; Zini, C. A.; J. Braz. Chem. Soc. 2015, 26, 1411.

8. Gabbardo, M.; Celotti, E.; Cienc. Tec. Vitivinic. 2015, 30, 94.
9. Calderone, G.; Guillou, C.; Reniero, F.; Naulet, N.; Food Res. Int. 2007, 40, 324.

10. Cabañero, A. I.; Rupérez, M.; Rapid Commun. Mass Spectrom. 2012, 26, 1753.

11. Carter, J. F.; Yates, H. S. A.; Tinggi, U.; J. Agric. Food Chem. 2015, 63, 975.

12. Gaillard, L.; Guyon, F.; Salagoïty, M.-H.; Médina, B.; Food Chem. 2013, 141, 2103.

13. Mardegan, S. F.; Andrade, T. M. B.; de Sousa Neto, E. R.; de Castro Vasconcellos, E. B.; Martins, L. F. B.; Mendonça, T. G.; Martinelli, L. A.; J. Food Compos. Anal. 2013, 29, 52.

14. Bontempo, L.; Caruso, R.; Fiorillo, M.; Gambino, G. L.; Perini, M.; Simoni, M.; Traulo, P.; Wehrens, R.; Gagliano, G.; Camin, F.; J. Mass Spectrom. 2014, 49, 785.

15. Cabañero, A. I.; Recio, J. L.; Rupérez, M.; J. Agric. Food Chem. 2010, 58, 722 .

16. Adami, L.; Dutra, S. V.; Marcon, Â. R.; Carnieli, G. J.; Roani, C. A.; Vanderlinde, R.; Rapid Commun. Mass Spectrom. 2010, 24, 2943.

17. Decreto No. 8.198, de 20 de fevereiro de 2014, Regulamenta a Lei No. 7.678, de 8 de Novembro de 1988, que Dispõe sobre a Produção, Circulação e Comercialização do Vinho e Derivados da Uva e do Vinho; Diário Oficial da União: Brasília, 2014, seção 1, p. 1.

18. Martinelli, L. A.; Moreira, M. Z.; Ometto, J. P. H. B.; Alcarde, A. R.; Rizzon, L. A.; Stange, E.; Ehleringer, J. R.; J. Agric. Food Chem. 2003, 51, 2625.

19. Dunbar, J.; Fresenius' Z. Anal. Chem. 1982, 311, 578.

20. Calderone, G.; Naulet, N.; Guillou, C.; Reniero, F.; Cortes, A. I. B.; Rapid Commun. Mass Spectrom. 2005, 19, 701.

21. Jos, A.; Moreno, I.; González, A. G.; Repetto, G.; Cameán, A. M.; Talanta 2004, 63, 377.

22. Pérez-Magariño, S.; Ortega-Heras, M.; Martínez-Lapuente, L.; Guadalupe, Z.; Ayestarán, B.; Eur. Food Res. Technol. 2013, $236,827$.

23. Scampicchio, M.; Eisenstecken, D.; de Benedictis, L.; Capici, C.; Ballabio, D.; Mimmo, T.; Robatscher, P.; Kerschbaumer, L.; Oberhuber, M.; Kaser, A.; Huck, C. W.; Cesco, S.; Food Anal. Methods 2016, 9, 1262.

24. Hohmann, M.; Monakhova, Y.; Erich, S.; Christoph, N.; Wachter, H.; Holzgrabe, U.; J. Agric. Food Chem. 2015, 63, 9666.

25. Portarena, S.; Gavrichkova, O.; Lauteri, M.; Brugnoli, E.; Food Chem. 2014, 164, 12.

26. Luo, D.; Dong, H.; Luo, H.; Xian, Y.; Wan, J.; Guo, X.; Wu, Y.; Food Chem. 2015, 174, 197.

27. Lei No. 10.970, de 12 de novembro de 2004, Altera Dispositivos da Lei No 7.678, de 8 de Novembro de 1988, que Dispõe sobre a Produção, Circulação e Comercialização do Vinho e Derivados da Uva e do Vinho, e dá Outras Providências; Diário Oficial da União: Brasília, 2004, seção 1, p. 1. 
28. Bruch, K. L.; Lei do Vinho Sistematizada; SEBRAE: Brasília, Brasil, 2012.

29. Perini, M.; Guzzon, R.; Simoni, M.; Malacarne, M.; Larcher, R.; Camin, F.; Food Control 2014, 40, 368.

30. International Organization of Vine and Wine (OIV); Compendium of International Methods of Wine and Must Analysis, vol. 1; OIV: Paris, France, 2016.

31. Ministério da Agricultura Pecuária e Abastecimento (MAPA); Instrução Normativa No. 24, de 08 de setembro de 2005, Aprova o Manual Operacional de Bebidas e Vinagres; Diário Oficial da União: Brasília, 2005, seção 1, p.11.

32. Bay, L. J.; Chan, S. H.; Walczyk, T.; J. Anal. At. Spectrom. 2015 , 30,310 .

33. Muccio, Z.; Jackson, G. P.; Analyst 2009, 134, 213.

34. Folch-Fortuny, A.; Arteaga, F.; Ferrer, A.; Chemom. Intell. Lab. Syst. 2015, 146, 77.

35. Folch-Fortuny, A.; Arteaga, F.; Ferrer, A.; Chemom. Intell. Lab. Syst. 2016, 154, 93.

36. Folch-Fortuny, A.; Arteaga, F.; Ferrer, A.; J. Chemom. 2016, 30, 386.

37. Iorizzo, M.; Macciola, V.; Testa, B.; Lombardi, S. J.; de Leonardis, A.; Eur. Food Res. Technol. 2014, 238, 1037.

38. Neto, F. S.; de Castilhos, M. B.; Telis, V. R.; Telis-Romero, J.; J. Sci. Food Agric. 2015, 95, 1421.

39. de Castilhos, M. B. M.; Conti-Silva, A. C.; del Bianchi, V. L.; Eur. Food Res. Technol. 2012, 235, 345.

40. de Castilhos, M. B. M.; Cattelan, M. G.; Conti-Silva, A. C.; del Bianchi, V. L.; LWT-Food Sci. Technol. 2013, 54, 360.

41. Caruso, M.; Galgano, F.; Castiglione Morelli, M. A.; Viggiani, L.; Lencioni, L.; Giussani, B.; Favati, F.; J. Agric. Food Chem. 2012, 60, 7 .

42. Alexandre, H.; Guilloux-Benatier, M.; Aust. J. Grape Wine Res. 2006, 12, 119.
43. Bordiga, M.; Rinaldi, M.; Locatelli, M.; Piana, G.; Travaglia, F.; Coïsson, J. D.; Arlorio, M.; Food Chem. 2013, 140, 57.

44. Hidalgo, P.; Pueyo, E.; Pozo-Bayón, M. A.; MartínezRodríguez, A. J.; Martín-Álvarez, P.; Polo, M. C.; J. Agric. Food Chem. 2004, 52, 6640.

45. Peinado, R. A.; Moreno, J. A.; Muñoz, D.; Medina, M.; Moreno, J.; J. Agric. Food Chem. 2004, 52, 6389.

46. Rhodes, C.; Heaton, K.; Goodall, I.; Brereton, P.; Food Chem. 2009, 114, 697.

47. Zea, L.; Moyano, L.; Moreno, J.; Cortes, B.; Medina, M.; Food Chem. 2001, 75, 79.

48. Styger, G.; Prior, B.; Bauer, F. F.; J. Ind. Microbiol. Biotechnol. 2011, 38, 1145.

49. Kemp, B.; Alexandre, H.; Robillard, B.; Marchal, R.; J. Agric. Food Chem. 2015, 63, 19.

50. Liger-Belair, G.; Polidori, G.; Jeandet, P.; Chem. Soc. Rev. 2008, 37, 2490.

51. Rossmann, A.; Schmidt, H.-L.; Reniero, F.; Versini, G.; Moussa, I.; Merle, M. H.; Z. Lebensm.-Unters. Forsch. 1996, 203, 293.

52. Aghemo, C.; Albertino, A.; Gobetto, R.; Spanna, F.; J. Sci. Food Agric. 2011, 91, 2088.

53. Costinel, D.; Tudorache, A.; Ionete, R. E.; Vremera, R.; Anal. Lett. 2011, 44, 2856.

54. Bro, R.; Smilde, A. K.; Anal. Methods 2014, 6, 2812.

55. Bartowsky, E. J.; Borneman, A. R.; Appl. Microbiol. Biotechnol. 2011, 92, 441.

56. Nisbet, M. A.; Tobias, H. J.; Brenna, J. T.; Sacks, G. L.; Mansfield, A. K.; J. Agric. Food Chem. 2014, 62, 6820.

Submitted: October 11, 2016

Published online: January 24, 2017

FAPERGS/CAPES has sponsored the publication of this article. 